\title{
Memórias do corpo, brincadeiras e construção de subjetividades
}

\section{Getulio \\ CHARTIER}

\section{Resumo}

A rua da casa de minha avó foi pátio para brincadeiras que permearam minha infância e parte da adolescência. Pano virava tenda de circo, papel virava chapéu e também barquinho para brincar na enxurrada da chuva. Nesta pesquisa, a brincadeira é abordada como recurso para manifestações de subjetividade que incluem imagens, representações e universos imaginários e não apenas como uma forma de diversão ou instrumento de socialização. Tais manifestações viajam nas fantasias, criam e recriam situações cotidianas e estabelecem condições de possibilidades para refletir e coletivizar experiências vividas em família, na escola e em outros espaços. O objetivo deste estudo é construir cruzamentos entre brincadeiras infantis, corpo, cultura e memória através da investigação de experiências com um grupo de futuras professoras. Nas brincadeiras, o corpo é tratado a partir de uma abordagem cultural, visto como lugar de enunciação de subjetividades. Como elementos centrais deste estudo, corpo e brincadeira deflagram sentidos determinantes na (re)construção de propostas de ensino-aprendizagem no campo da educação da cultura visual. Meu interesse nesta investigação é compreender como futuras professoras dão significado à experiência do brincar, que vínculos criam entre o brincar e a formação docente e, como entendem a função da brincadeira nas suas vidas pessoal e profissional.

Palavras-chave: Brincadeiras, corpo, memória. 